\title{
Transformation of Graduate Education in Applied Anthropology in the U.S.: Learning and Teaching Policy Studies
}

\section{Introduction to the Special Issue}

When engaged in doctoral research (1972) on urban squatter settlements in the Philippines, Feldman's approach was guided by the pedagogy of Paulo Freire (2005[orig.1970]), which gratefully steered his behaviour away from the typical 'Ugly American' abroad in the world at the time (during the Vietnam War). Feldman became aware of the notions of 'teacher-student' and of 'student-teacher' primarily through his discussions with two Filipino doctors, Jess and Trini de la Paz (a husband and wife team), who organised a health education and training programme for volunteer participants from 12 squatter settlements in Davao City on the southern island of Mindanao. They invited him to serve as a social science consultant for their project. They explained that their approach to health education and training was grounded in, and would always adhere to, Freire's insistence that oppressed people should be viewed as teachers for anyone engaging in their instruction or assistance, requiring that their teachers also become their students in understanding or assisting their lives. Freire wrote:

... the problem-posing educator constantly re-forms his reflections in the reflection of the students. The students - no longer docile listeners - are now critical co-investigators in dialogue with the teacher ... Authentic reflection considers neither the abstract man nor the world without people, but people in their relations with the world. In these relations consciousness and world are simultaneous: consciousness neither precedes the world nor follows it (Freire 2005 [orig. 1970]: 81).

During their academic careers, graduate students often find themselves in structurally generated conditions, lacking the power of self- 
direction and curricular development that result in passive learning. Two of Henry's students co-authored a paper for the Society for Applied Anthropology (SfAA) conference in Vancouver, in which they explored the power differentials in higher education (Luster and Manoochehri 2006). Specifically, they highlighted the effects of power differentials that exist in graduate anthropology departments and called attention to the parallels between graduate students and untenured faculty as they experience uncertainty in their authority and identity within the department. They discuss how those in power within the department and in upper administration influence students' ability to freely pursue projects according to their own interests and how this influence may affect future pedagogical processes. Faculty often proclaim to students the importance of empowering others, of participatory action research, open inquiry and the like; yet, at the same time, they frequently exert strong authority and control over students' educational and career pursuits. Faculty can exert the intellectual and moral authority of a hegemon (leader) that persuades graduate students to accept and adopt their imposed powerless situation. Force is not needed; students accept the authority 'spontaneously'. These faculty/ student relationships could lead students to become enskilled in simi-

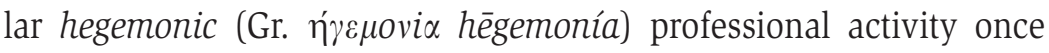
they graduate. The papers in this volume highlight graduate student empowerment of their own intellectual paths.

The history of applied anthropology in the U.S. (Eddy and Partridge 1987) reflects the gradual shift from top-down social change projects initiated by academic anthropologists to working side by side with communities, as described here in Vásquez-Léon et al.'s essay (also see Gwynne 2003; Kedia and van Willigen 2005; McDonald 2002; and Feldman, Langdon and Natcher 2005). Translating the professionally learned values of empowering local groups via Participatory Action Research (PAR) to departmental programmes for training and educating future applied social science scholars has been slower in coming.

The essays in this issue demonstrate the pedagogical power of graduate students' engagement in their own academic formation as scholars, international conference organisers and applied social sci- 
ence researchers (see Mills and Harris 2004 for research on educating anthropologists today). Implicit in the narratives of each paper is an emphasis on embodied learning (Skinner 2005) as an essential component of how humans as social beings know and acquire knowledge (Ingold 2002; Lave and Wenger 1991). Just as fieldwork in cultural anthropology requires the embodied learning experienced by researchers that flows from participant observation aimed at understanding sociocultural alterity, the education of and programmes for anthropological or other social science graduate students involve embodied learning by both faculty and students, whether they realise it or not. Active student participation in their graduate educational experiences imprints their individual (and hopefully departmental l'ame collective) body/mind learning and understanding. Such encouragement of student input and action into their own professional formation prepares the students for a lifelong habit (or professional habitus) as educators, applied social scientists and researchers. That is, as professionals, they consciously seek in their teaching, research or service to be part of a process where everyone involved discovers, as Freire noted, how to participate in the transformation of their world.

The papers in this issue of Learning and Teaching were authored by anthropological graduate students and professors in the U.S. who share these pedagogical values from three different institutions and programmes of higher education: George Mason University, American University and the University of Arizona. ${ }^{1}$ The impetus for the papers derived from a session at the annual meeting of the Society for Applied Anthropology (SfAA) in 2008 in Memphis, Tennessee, proposed by Kerry Feldman and Lisa Henry on behalf of the Consortium of Practicing and Applied Anthropology Programs (COPAA), with 23 member departments. This organisation was formed a decade earlier at the SfAA meetings in Memphis, and originated by two former presidents of SfAA, Linda Whiteford (University of South Florida) and Linda Bennett (University of Memphis), both of whom are well-known medical anthropologists and presently academic administrators. COPAA's mission (http://www.copaa.info/) is to enhance the education programmes of applied anthropolo- 
gists, in conjunction with practising anthropologists (anthropologists working outside of academia). COPAA also provides advice to nonmember departments or universities requesting assistance on the development of applied anthropology, in the U.S. or abroad. This year, a department in Ireland sought advice regarding how to structure an experiential-based bachelor's degree programme in applied anthropology (see Indiana University - Purdue University at Indianapolis http://www.copaa.info/programs_in_aa/list.htm\#sc11). COPAA, under the leadership of Lisa Henry, sponsored several sessions at the SfAA meetings, and invited Sue Wright (Danish School of Education, Aarhus University) as its first distinguished international lecturer to present a paper on policy and applied anthropology. Additionally, she served as a co-discussant for our session on how to teach policy studies to graduate students with Tom Greaves (former president of SfAA, editor of the journal, American Anthropologist, human rights advocate and scholar). The discussants noticed how the papers in our session included the significance of student voices in shaping their own educational experience, not only as voices formed by faculty instruction. At the invitation of Sue Wright, our authors revised their papers for this volume of Learning and Teaching to focus on narratives that identify how students have influenced and shaped their own learning.

Originally, we invited papers for our session from innovative applied anthropologists, including one male/female graduate student team from the American University, who were experienced in applied anthropology projects or programmes involving policy education and analysis. We wanted papers presented on topics that were at the heart, not the periphery, of social challenges today, reflecting globalisation forces. Three of the four invited papers are published here. ${ }^{2}$ The foci of these papers include policing and surveillance related to the ' $9 / 11$ ' U.S. terrorist experience, as well as other worldwide terrorist events, by graduate students Viteri and Tobler; graduate conflict resolution education by Avruch; and cooperative agricultural development programmes in South America by Vásquez-Léon, Burke and Radonic ${ }^{3}$ (graduate students are co-authors with Vásquez-Léon). 
The 'show-stopper' of our session was the paper presented by two doctoral students from American University, Maria Amelia Viteri (now Dr Viteri) and Aaron Tobler. They describe how they organised an international conference on policing and surveillance at the American University in Washington, DC in 2007. The conference is now in its third year and continues to be organised by graduate students with guidance by Viteri. They had to negotiate departmental and college challenges to initially offer this conference, enlist local and often marginalised activist groups, and confront normal graduate student apathy regarding any activity not directly related to their own degree seeking goals.

Avruch's paper describes how both theory and method in the education of conflict resolution specialists benefitted from the involvement of students from developing nations and marginalised populations. These students had years of experiential maturity to draw on in demanding and developing, with anthropological faculty, courses focused on the cultural dimensions of both conflict and resolution, without simply relying on abstract theories of western social psychology that often dominated such training programmes. From their own experiences, these students knew that each culture identifies 'conflict', and also knew how to resolve it without bloodshed, in culturally specific ways, contrary to universalist fantasies about 'human nature' often found in the field of psychology.

Vásquez-Léon and her graduate student co-authors at the University of Arizona, Burke and Radonic, reflect on three completed field seasons in Brazil and Paraguay devoted to agricultural cooperatives in which student researchers, including in-country undergraduate students from partner universities, were critical components.

Finally, if the people we work among and examine are always gendered, aged and cultured, we thought that our topic should be explored from diverse perspectives. We intentionally invited authors diverse in gender, age and ethnicity (policy, after all, can affect and be perceived by diverse populations differently). Maria Amelia Viteri is a graduate student (now holding a doctorate in anthropology) from Ecuador and Marcela Vásquez-Léon is from Colombia. These female voices are 
intertwined with male and female graduate student voices involved in their projects. They are joined with perspectives by an AngloAmerican male author, Kevin Avruch, a senior scholar in his field. We hope that the manner in which we structured our session and published the papers here creates a holistic, polyphonic result. Understanding the implications of any 'culture of policy' in a university or in social science programmes requires an attention to the resulting meanings and lived experiences for students. The many voices in these essays invite dialogue from across the Atlantic with regard to the role of graduate students in shaping their educational praxis in a globalising world.

We invite readers of Learning and Teaching to participate in the 2010 meetings of SfAA in Merida, Mexico (http://www.sfaa.net/).

\section{Kerry D. Feldman}

Department of Anthropology, University of Alaska Anchorage

Email: afkdf@uaa.alaska.edu

\section{Lisa Henry}

Department of Anthropology, University of North Texas

Email: lisa.henry@unt.edu

\section{Notes}

1. George Mason University (2007) and American University (2009) are located on the east coast of the U.S.A. in Washington, DC. The University of Arizona (2009) is located in the U.S. southwest in the state of Arizona. George Mason University began in 1957 as a branch of the University of Virginia, becoming independent in 1972. The University of Virginia (2009) opened to its first students in 1825, one of the earliest state-funded universities in the U.S. Thomas Jefferson was the key proponent of the University of Virginia, establishing it as non-sectarian, which was unusual for many state-funded universities in early U.S. history. American University was chartered by the U.S. Congress in 1893, not by a state, and began in 1896 by the Methodist Church, which still provides United Methodist Church accreditation. The University of Arizona was approved by a Territorial Legislature in 1885 before Arizona became a state in the U.S. Its colourful western history is seen in its origin on land owned by two gamblers. The Bureau of Applied Research in Anthropology (BARA) was founded in 1952 as the Bureau of Ethnic Research (2009) to monitor the socio-economic situation of Native American communities in Arizona. In 1982, BARA changed its name and adopted an international mission. 
2. The paper by Ray Barnhardt, of the University of Alaska Fairbanks, on enhancing graduate degree completion by Alaska Native students, is being published in a Canadian journal of education.

3. Márcela Vazquez-Léon could not deliver her paper at the session due to a last-minute schedule conflict. She co-authors it here with graduate students from the University of Arizona.

\section{References}

Consortium of Practicing and Applied Anthropology Programs (COPAA), < http:// www.copaa.info/ > (accessed 29 March 2009) and < http://www.copaa.info/ programs_in_aa/list.htm\#sc11 > (accessed 29 March 2009).

Eddy, E. M. and Partridge, W. L. (eds) (1987) Applied Anthropology in America, 2nd ed., New York: Columbia University Press.

Feldman, K. D., Langdon, S. J. and Natcher, D. C. (2005) 'Northern Engagement: Alaskan Society and Applied Cultural Anthropology, 1973-2003', Alaska Journal of Anthropology, 3, no. 1: 121-155.

Freire, P. (2005 [orig.1970]) Pedagogy of the Oppressed, New York: Continuum.

Gwynne, M. A. (2003) Applied Anthropology: A Career-Oriented Approach, Boston: Allyn and Bacon.

Ingold, T. (2002) 'Learning is understanding in practice: exploring the relations between perception, creativity and skill', Arts and Humanities Research Council research grant (2002-2005), < http://www.abadn.ac.uk/anthropology/ti.shtml > .

Kedia, S. and Willigen, J. van (eds) (2005) Applied Anthropology: Domains of Application, Westport: Praeger.

Lave, D. and Wenger, E. (1991) Situated Learning: Legitimate Peripheral Participation, Cambridge: Cambridge University Press.

Luster, G. and Manoochehri, R. (2006) 'Power differentials in higher education', paper presented at the sixty-eighth meeting of the Society for Applied Anthropology.

McDonald, J. H. (ed.) (2002) The Applied Anthropology Reader, Boston: Allyn and Bacon.

Mills, D. and Harris, M. (eds) (2004) Teaching Rites and Wrongs: Universities and the Making of Anthropologists, The Higher Education Academy Network Monograph, no. 2, Birmingham: Centre for Sociology, Anthropology, Politics (C-SAP), $1-19$.

Skinner, J. (2005) 'Editorial', Anthropology in Action: Journal for Applied Anthropology in Policy and Practice, 12, no. 2: v-ix. 